\title{
Article
}

http://dx.doi.org/10.11646/phytotaxa.172.1.6

\section{Pitcairnia albifolia (Bromeliaceae), a new species from the Talamanca Mountains in Veraguas Province, Panama}

\author{
DANIEL ADOLFO CÁCERES GONZÁLEZ ${ }^{1}$ \& ALICIA IBÁÑEZ ${ }^{2}$ \\ ${ }^{1}$ UCH Herbarium of the Universidad Autónoma de Chiriqui, David, Chiriqui, Republic of Panama, 0427 Estafeta Universitaria, David, \\ Chiriquí, Panamá; and Herbarium Senckenbergianum Frankfurt/Main (FR), Germany; Email: consultoria.caceres@gmail.com \\ ${ }^{2}$ Smithsonian Tropical Research Institute, Research Collaborator, Avenida Roosevelt, Edificio Tupper 401, Balboa, Ancón, Republic of \\ Panama; Email: ibaneza@si.edu
}

\section{Introduction}

Bromeliaceae Juss. comprises 3,348 species and 58 genera (Luther 2012), grouped in subfamilies Brocchinioideae, Bromelioideae, Hechtioideae, Lindmanioideae, Navioideae, Pitcairnioideae, Puyoideae, and Tillandsioideae (Givnish et al. 2007). According to Luther (2012), the genus Pitcairnia Ruiz \& Pav. has ca. 342 species and is the most diverse in Pitcairnioideae.

In Panama, Cáceres González et al. (2011) reported the Bromeliaceae to comprise 206 species in 7 genera; the genus Pitcairnia including 23 species, with 6 of them endemics and two species previously not known from Panama, $P$. halophila L.B. Smith (1964: 32) and P. wendlandii Baker (1881: 306). Recently Guzmania panamensis Cáceres González (2013: 69) was published from Panama; this species has been collected in Santa Fe National Park (Western Panama). However, no new taxa of Pitcairnia have been described from Panama since Grant (1998).

This new species, Pitcairnia albifolia, was collected during a fieldtrip to the Santa Fe National Park, Veraguas Province, Panama, in July 2009, as part of a general floristic survey of a region locally called La Sabaneta, on the poorlyexplored Caribbean mountain forests. The La Sabaneta area is found along the colonial Camino de Chilagre from Santa Fe to the Mines of Concepción and has been burned in the past (personal communication with locals), evidenced by seeing charcoal. Subsequently, herbarium collections of Pitcairnia from 12 herbaria (B, CR, FR, INB, MO, NY, PMA, SCZ, SEL, UCH, USJ and WU; abbreviations from Thiers [continuously updated]) were studied, confirming that the Santa Fe National Park region is a poorly collected area. This is principally due to difficult orography, access and the ecological landscape that make it a place with a great potential for the discovery of new species. It was found that the specimen did not match any of the known taxa of the genus and, hence, is described and illustrated here as a new species.

Pitcairnia albifolia Cáceres González \& A. Ibáñez, sp. nov. (Fig. 1-3)

Type:-PANAMA. Veraguas Prov.: Distr. Santa Fe, Santa Fe National Park, La Sabaneta, premontane rain forest, elevation 1100 m, 08 40’38.70” N, 80 59’31.00” W, 15 July 2009, Fermín Hernández, José Guerra, Victor Concepción \& Alicia Ibáñez 5731 AI (holotype: PMA!; isotype: UCH!).

This new species is similar to Pitcairnia nigra, but differs from it by its floral bracts that are shorter (4-6 mm long) and flowers pedicellate (up to $5 \mathrm{~mm}$ long), vs. floral bracts longer (65-80 mm long) and flowers sessile. The leaves in Pitcairnia albifolia are shorter (12.5-16.0 cm long $\times 3-4 \mathrm{~cm}$ wide) and adaxially densely covered with white lepidote trichomes; whereas the leaves in P. nigra are longer (60-67 cm long $\times 10-14 \mathrm{~cm}$ wide) and soon glabrous.

Plant terrestrial or saxicolous, acaulescent with a semi-erect short rhizome ca. $11 \mathrm{~cm}$ long and $3 \mathrm{~cm}$ diameter, covered by the densely imbricate old leaf-bases and roots, flowering ca. $52 \mathrm{~cm}$ high, normally individual plant with few leaves (5-7). Leaves semi-arching, homomorphic, persisting, petiolate, entire, stiff-chartaceous, $12.5-16.0 \mathrm{~cm}$ long, much shorter than the inflorescence; petiole $2.5-3.0 \mathrm{~cm}$ long, $0.5-1.5 \mathrm{~cm}$ wide, chartaceous, venation conspicuous, margins entire, white-lepidote on both sides; blades ovate-lanceolate to elliptic, 9-12 cm long $\times 3-4 \mathrm{~cm}$ wide $(3-4$ times longer 


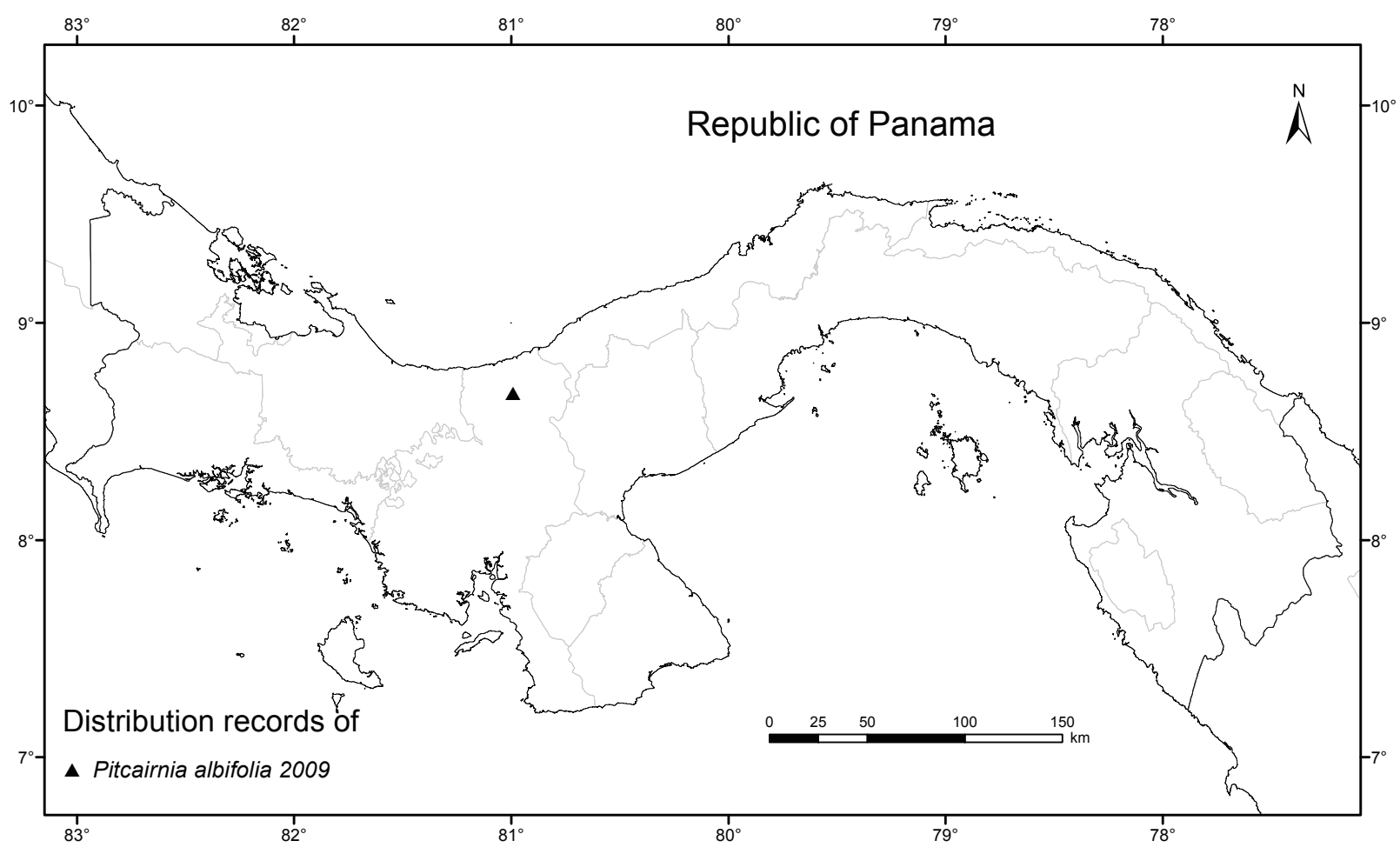

FIGURE 3. Geographical distribution of Pitcairnia albifolia. Map created by D. A. Cáceres González using ArcGIS Version 10.2.

\section{Acknowledgements}

The authors wish to thank the curators of the herbaria B, CR, FR, INB, MO, NY, PMA, SCZ, SEL, UCH, USJ, and WU for allowing access to their collections; the Autoridad Nacional del Ambiente (ANAM) for facilitating this research through issuing the collecting permit (SE/P-19-09); the Smithsonian Tropical Research Institute (STRI) for supporting all logistical aspects of this work; and the US National Institutes of Health for funding the fieldwork through the International Cooperative Biodiversity Groups (ICBG) program.

We would also like to thank the botanist Fermín Hernández, who was research assistant during the trip and introduced the La Sabaneta region to one of the authors (Ibáñez); UCH Herbarium of the Universidad Autónoma de Chiriquí and Consultoría Ambiental Cáceres for providing the facilities to one of the authors (Cáceres González). Finally, we are grateful to Jerry Harrison and the anonymous reviewers for language editing and suggestions.

\section{References}

André, E.F. (1888). Enumeration des Bromeliacées, recoltées en 1875-1876 dans l'Amerique du Sud. Revue Hortic 60: 563-568.

Baker, J.G. (1881) A synopsis of the genus Pitcairnia. Journal of Botany 19: 303-308.

Cáceres González, D.A., Schulte, K., Schmidt, M. \& G. Zizka (2011) A synopsis of the Bromeliaceae of Panama, including new records for the country. Willdenowia 41: 357-369.

http://dx.doi.org/10.3372/wi.41.41216

Cáceres González, D.A. (2013) Guzmania panamensis (Bromeliaceae) - a new species from Talamanca Mountain in Veraguas province, Western Panama. PhytoKeys 25: 69-74. http://dx.doi.org/10.3897/phytokeys.25.5174

Carrière, E.A. (1881) Neumannia nigra. Revue Horticole 53: 390-391.

Evans, R.J. (2001) Monograph of Colpothrinax. Journal of the International Palm Society 45(4): 177-195.

Givnish, T.J., K.C. Millam, P.E. Berry \& K.J. Sytsma. 2007. Phylogeny, Adaptive Radiation, and Historical Biogeography of Bromeliaceae inferred from ndhF Sequence data. Aliso 23: 3-26. 
Grant, J.R. (1998) Notes on Mesoamerican Pitcairnia I. Journal of The Bromeliad Society 48: 99-105.

IUCN (2001) The IUCN Red List categories and criteria, version 3.1. IUCN Species Survival Commission. Gland, Switzerland and Cambridge, U.K. Available from: http://www.iucnredlist.org/technical-documents/categories-and-criteria/2001-categories-criteria (accessed: 10 August 2013).

Luther, H.E. (2012) An alphabetical list of bromeliad binomials. Thirteenth edition. Marie Selby Botanical Gardens and Bromeliad Society. International.

Smith, L.B. (1964) Notes on Bromeliaceae, XXI. Phytologia 10: 1-55.

Thiers, B. (continuously updated) Index herbariorum: a global directory of public herbaria and associated staff. New York Garden's Virtual Herbarium. Available from: http://sweetgum.nybg.org/ih/herbarium.php?irn=174420 (accessed: 12 August 2013). 